\title{
Agro-economic performance of the association of beet with green cowpea in different amounts of hairy woodrose
}

\author{
Daciano M. de Sousa ${ }^{1}$, Francisco Bezerra Neto ${ }^{1}$, Jailma S. S. de Lima ${ }^{1}$, \\ Grace K. L. de Lima ${ }^{1}$, Aridênia P. Chaves ${ }^{1}$ \& Josimar N. da Silva ${ }^{1}$
}

\begin{abstract}
${ }^{1}$ Universidade Federal Rural do Semi-Árido/Departamento de Ciências Agronômicas e Florestais. Mossoró, RN. E-mail: dacianomiguel@hotmail.com - ORCI 0000-0001-6130-142X (Corresponding author); bezerra@ufersa.edu.br - ORCID: 0000-0001-9622-206X; jailma@ufersa.edu.br - ORCID: 0000-0001-7584592X; gracekllagro@gmail.com - ORCID: 0000-0002-2102-4285; aridenia.peixoto@gmail.com - 0000-0002-2184-2536; josimar2160@hotmail.com - ORCID: 0000-0002-8019-9501
\end{abstract}

Key words:

Beta vulgaris L.

Vigna unguiculata L.

Merremia aegyptia L.

intercropping

\begin{abstract}
A B S T R A C T
Intercropping systems of beet and green cowpea are beginning to be implemented in the northeastern semi-arid region in Brazil. The great challenge is to know if there is agroeconomic efficiency in these systems when fertilized with organic matter produced by spontaneous species of the Caatinga biome. Thus, the objective of this research was to evaluate the effect of green manuring using different amounts of hairy woodrose (Merremia aegyptia) in the association of beet with green cowpea under the semi-arid conditions. The experiment was carried out at the Rafael Fernandes Experimental Farm, rural area of Mossoró, RN, Brazil, in the period of September-December 2015, in a randomized complete block design with four treatments and five replicates. The treatments consisted of hairy woodrose amounts incorporated into the soil $\left(10,25,40,55 \mathrm{t} \mathrm{ha}^{-1}\right.$ on a dry basis). The cultivars of beet and green cowpea planted were 'Early Wonder' and 'BRS Itaim', recommended for the semi-arid conditions of the Brazilian Northeast. The best agro-economic performance for intercropping system of beet and green cowpea was obtained with $55 \mathrm{t} \mathrm{ha}^{-1}$ of hairy woodrose incorporated in the soil. The use of the hairy woodrose species as green manure is agronomically viable in intercropped systems with beet and green cowpea.
\end{abstract}

\section{Palavras-chave:}

Beta vulgaris L. Vigna unguiculata L. Merremia aegyptia L. consórcio

\section{Desempenho agroeconômico da associação beterraba com caupi-hortaliça em diferentes quantidades de jitirana}

\section{R E S U M O}

Sistemas consorciados de beterraba $\mathrm{x}$ caupi-hortaliças estão começando a ser implantados no semiárido nordestino. O grande desafio é saber se existe ou não eficiência agroeconômica nesses sistemas quando adubados com matéria orgânica produzida por espécies espontâneas do bioma Caatinga. Assim, o objetivo desta pesquisa foi avaliar o efeito da adubação verde utilizando diferentes quantidades de jitirana (Merremia aegyptia) na associação de beterraba com caupi-hortaliça nas condições do semiárido. O experimento foi realizado na Fazenda Experimental Rafael Fernandes, zona rural de Mossoró, RN, no período de setembro-dezembro de 2015, em delineamento experimental de blocos casualizados com quatro tratamentos e cinco repetições. Os tratamentos consistiram de quantidades de jitirana incorporadas ao solo $\left(10,25,40,55 \mathrm{t} \mathrm{ha}^{-1}\right.$ em base seca). As cultivares de beterraba e do caupi-hortaliça plantadas foram 'Early Wonder' e 'BRS Itaim', recomendadas para as condições semiáridas do Nordeste brasileiro. O melhor desempenho agroeconômico para o consórcio de beterraba e caupi-hortaliça foi obtido com $55 \mathrm{t} \mathrm{ha}^{-1}$ de jitirana incorporada ao solo. O uso da espécie jitirana como adubo verde é agronomicamente viável em sistemas consorciados de beterraba com caupi-hortaliça. 


\section{INTRODUCTION}

Intercropping between vegetables has increased in Northeast Brazil, particularly in agroecological systems, presenting various advantages in the productive, nutritional, economic and environmental aspects (Almeida et al., 2015), and promotes maximization of yield per unit of cultivated area, making better use of natural resources such as soil, water, light and nutrients, besides leading to higher efficiency in the use of labor (Sediyama et al., 2014).

In addition, compared with mono cultivation, this practice leads to various advantages, such as vegetative protection of soil against erosion and control of weeds (Devide et al., 2009), besides promoting higher frequency of profits to the small farmer, due to the diversification of products per area planted (Alves et al., 2009).

Hence, given the various advantages that the intercropping provides to vegetable producers, many studies have been conducted and demonstrated the efficiency of this cultivation system, including those involving the intercropping of coriander x carrot (Fernandes et al., 2011), carrot x green cowpea (Favacho et al., 2017) and lettuce $\mathrm{x}$ arugula (Almeida et al., 2015), which reveal an indication of possibilities to verify the efficiency of other associations.

Nonetheless, one of the factors related to intercropped cultivation and little studied is the fertilization of the crops involved. Among the existing fertilization practices, green manuring plays a preponderant role in the development and production of vegetables aiming at maximum use of the resources available in the agricultural property (Oliveira et al., 2011).

The Caatinga biome has various spontaneous species with potential for use in green manuring, including hairy woodrose (Merremia aegyptia L.) (Silva et al., 2011). Bezerra Neto et al. (2014), using hairy woodrose as green manure in carrot production, obtained commercial yield of $32.11 \mathrm{tha}^{-1}$ with the quantity of $15.54 \mathrm{t} \mathrm{ha}^{-1}$.

In beet, the use of hairy woodrose incorporated led to maximum commercial yield of $9.80 \mathrm{t} \mathrm{ha}^{-1}$, obtained with the dose of $15.6 \mathrm{t} \mathrm{ha}^{-1}$ (Silva et al., 2011). However, for the cultivation of beet associated with green cowpea, there is no scientific information in the literature on the adequacy of this fertilization.

Therefore, this study aimed to evaluate the effect of green manuring using different amounts of hairy woodrose in the agro-economic evaluation of the association of beet with vegetable cowpea under semi-arid conditions.

\section{Material AND Methods}

The research was conducted from September to December 2015 at the Rafael Fernandes Experimental Farm, of the Federal Rural University of the Semi-Arid Region - UFERSA, located in the district of Alagoinha, rural area of MossoróRN, Rio Grande do Norte, Brazil (50 03’ S; 37 24’ W; 18 m). Tillage consisted in one harrowing, followed by raising of beds using a rotary hoe and solarization at pre-planting with 30-micron transparent plastic (Vulcabrilho Bril Fles), for 30 days, to combat phytoparasites in the $0-10 \mathrm{~cm}$ soil layer (Silva et al., 2006).

The experimental design was randomized complete blocks with four treatments and five replicates. Treatments consisted of four amounts of hairy woodrose $\left(10,25,40,55 \mathrm{tha}^{-1}\right.$ on dry basis) incorporated to the soil.

Intercropped cultivation was established in alternated strips of the crops at proportion of $50 \%$ of the area for beet and $50 \%$ of the area for green cowpea, where each plot comprised four beet rows alternated with four green cowpea rows, surrounded by two border rows of beet on one side and by two green cowpea rows on the other, constituting the lateral borders. The total area of the plot was $3.60 \mathrm{~m}^{2}$, with evaluation area of $2.00 \mathrm{~m}^{2}$, containing 100 beet plants and 40 green cowpea plants at spacing of $0.25 \times 0.04 \mathrm{~m}$ and $0.25 \times$ $0.10 \mathrm{~m}$, respectively.

Beet and green cowpea cultivars were respectively 'Early Wonder' and 'BRS Itaim', which are recommended for the semi-arid conditions of Northeast Brazil. Single plots of each vegetable studied were planted in each block to obtain the intercropping efficiency indices. For beet, the total area of the plot was $1.44 \mathrm{~m}^{2}$, with evaluation area of $0.80 \mathrm{~m}^{2}$, at spacing of $0.20 \times 0.10 \mathrm{~m}$. For green cowpea, total area was $3.60 \mathrm{~m}^{2}$, with evaluation area of $2.00 \mathrm{~m}^{2}$, at spacing of $0.50 \times 0.10 \mathrm{~m}$. Plant populations for single cultivation of beet and green cowpea were 500,000 and 200,000, according to the methodologies of Silva et al. (2011) and Santos (2011), respectively.

The amount of hairy woodrose used in the mono cultivation of beet was $45 \mathrm{t} \mathrm{ha}^{-1}$, as recommended by Bezerra Neto et al. (2014); for green cowpea, the amount was $47 \mathrm{t} \mathrm{ha}^{-1}$ (data not published).

Hairy woodrose used as green manure was collected from the native vegetation close to Mossoró- $\mathrm{RN}$, at early flowering. After collection, plants were cut in a conventional forage machine to obtain fragments of approximately 2.0 to 3.0 $\mathrm{cm}$ and dehydrated under sunlight, until reaching moisture content of $10 \%$.

The green manure was incorporated to the experimental plots twice, $50 \%$ of the amounts of hairy woodrose at 21 days before sowing and $50 \%$ at 35 days after planting, according to the methodology used by Favacho et al. (2017), based on the cycle of the root-vegetable as main crop.

To determine the contents of nutrients in the green manure, samples were collected and sent to the Soil Fertility and Plant Nutrition Laboratory of the Department of Environmental and Technological Sciences of the UFERSA for analyses of nitrogen $(\mathrm{N})$; phosphorus $(\mathrm{P})$; potassium $\left(\mathrm{K}^{+}\right)$; calcium $\left(\mathrm{Ca}^{2+}\right)$ and magnesium $\left(\mathrm{Mg}^{2+}\right)$, as per methodologies recommended by EMBRAPA (2009), obtaining the following values: $11.40 \mathrm{~g} \mathrm{~kg}^{-1}$ of N; $2.36 \mathrm{~g} \mathrm{~kg}^{-1}$ of P; $2.20 \mathrm{~g} \mathrm{~kg}^{-1}$ of K+; $8.30 \mathrm{~g} \mathrm{~kg}^{-1}$ of $\mathrm{Ca}^{2+}$ and $9.75 \mathrm{~g} \mathrm{~kg}^{-1}$ of $\mathrm{Mg}^{2+}$.

Irrigations were performed twice (morning and afternoon) providing in both periods a water depth of approximately $8 \mathrm{~mm}$ day $^{-1}$ (Lima et al., 2010), in order to favor soil microbial activity in the decomposition process. Along the experiment, manual weeding was performed to control invasive plants. 
Beet and green cowpea were sown in simultaneous cultivation on October 13, 2015, in approximately 3-cm-deep holes, planting 4 and 2 seeds per hole, respectively. At 14 and 10 days after sowing (DAS), beet and green cowpea plants were thinned, respectively.

Beet was harvested 70 days after planting, while green cowpea harvest started at 52 days after planting. The fifth and last harvest was carried out at 66 days after planting.

Beet plants were evaluated for the following characteristics: total yield, commercial yield and classified root yield, shoot dry matter and root dry matter. In green cowpea, the characteristics evaluated were: number of grains per pod, yield of green pods, number of pods $\mathrm{m}^{-2}$, yield of green grains, dry matter of green grains and dry matter of green pods.

Agro-economic indices were: area equivalence index (AEI), defined by the expression:

$$
\mathrm{AEI}=\left(\frac{\mathrm{Y}_{\mathrm{bvc}}}{\mathrm{Y}_{\mathrm{bs}}}\right)+\left(\frac{\mathrm{Y}_{\mathrm{vcb}}}{\mathrm{Y}_{\mathrm{vcs}}}\right)
$$

where:

$\mathrm{Y}_{\mathrm{bvc}}$ - beet yield intercropped with vegetable cowpea;

$\mathrm{Y}_{\mathrm{bs}}$ - beet yield in mono cultivation;

$\mathrm{Y}_{\mathrm{vcb}}$ - green cowpea yield intercropped with beet; and,

$\mathrm{Y}_{\mathrm{vcs}}$ - green cowpea yield in mono cultivation.

Production efficiency index (PEI) was calculated to evaluate the production efficiency of each treatment, using the PEI models with constant returns to scale (Charnes et al., 1978).

Gross income was obtained by multiplying the yields of the crops in each treatment by the value of the product paid to the producer (R\$2.40 and $\mathrm{R} \$ 7.50 \mathrm{~kg}^{-1}$ for beet and green cowpea, respectively). Net income was calculated by deducting from the gross income the costs of production, relative to inputs and services. Return rate was obtained by the relationship between gross income and total cost, which corresponds to how much money ( $\mathrm{R} \$$ ) is obtained for each $\mathrm{R} \$ 1.00$ applied in costs of production of the evaluated intercropping system. Profitability index was obtained by the relationship between net income and gross income, expressed in percentage, according to the methodology of Silva et al. (2017).

Univariate analysis of variance was carried out to evaluate the characteristics of beet and green cowpea, using the software SISVAR (Ferreira, 2011). Regression analysis was also conducted for the evaluated characteristics as a function of the amounts of hairy woodrose incorporated to the soil, using the software application Table Curve (Jandel Scientific, 1991).

\section{Results AND Discussion}

Total and commercial yield of beet showed an increasing performance as a function of the amount of hairy woodrose incorporated, with values of 13.97 and $12.46 \mathrm{tha}^{-1}$ respectively at the highest amount of hairy woodrose incorporated (Figures 1A and B).

The commercial yield found in the present study was higher than that reported by Linhares et al. (2012), who
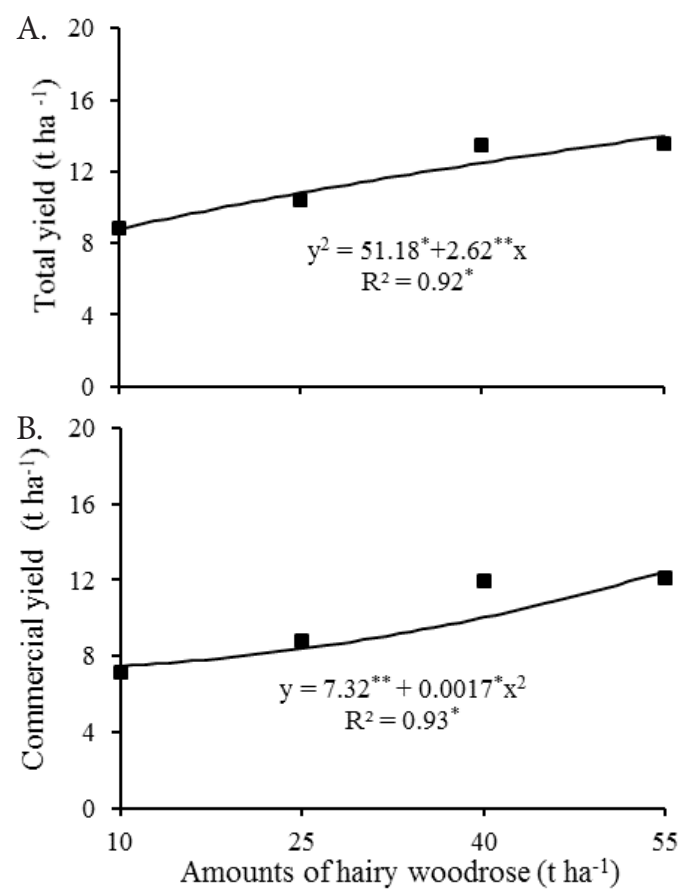

Figure 1. Total beet yield (A) and commercial yield (B) as a function of amounts of hairy woodrose incorporated to the soil

evaluated amounts of Carnauba straw in beet and obtained mean commercial yield of $9.80 \mathrm{tha}^{-1}$. These results may be due to the adequate supply of amounts of $\mathrm{N}$ incorporated, thus promoting growth, vegetative development, photosynthetic area expansion, activation and increase in production potential of the crop (Favacho et al., 2017). The plant material used, hairy woodrose, had $\mathrm{K}$ content of $11.40 \mathrm{~g} \mathrm{~kg}^{-1}$; thus, there was synchronization between nutrient release factors and the period of nutritional demand of the crop.

The yield of extra and scrap roots of beet decreased with the increase in the amounts of hairy woodrose incorporated to the soil, and the best results were obtained with the lowest amount of hairy woodrose, 2.98 and $1.64 \mathrm{t} \mathrm{ha}^{-1}$, respectively (Figures 2A and $\mathrm{D}$ ). These values indicate that the higher the amount of green manure incorporated to the soil, the higher the increment in production, reducing the yield of beet roots for disposal, which makes this characteristic important for the producer.

Yield of extra A roots showed increasing performance as a function of the amounts of hairy woodrose incorporated to the soil, and its highest value $\left(2.61 \mathrm{t} \mathrm{ha}^{-1}\right)$ was obtained with the amount of $55 \mathrm{t} \mathrm{ha}^{-1}$ of the green manure (Figure $2 \mathrm{~B}$ ). For the yield of extra AA + large roots, an increase was observed and its highest value $\left(7.76 \mathrm{t} \mathrm{ha}^{-1}\right)$ was obtained with the amount of $47.37 \mathrm{t} \mathrm{ha}^{-1}$, decreasing from this point until the last amount of hairy woodrose added (Figure $2 \mathrm{C}$ ). These results demonstrate the responsiveness of the crop to the addition of nutrients through the green manure.

Beet shoot and root dry matter also increased as the amounts of hairy woodrose incorporated to the soil increased, with maximum values of 2.99 and $2.91 \mathrm{tha}^{-1}$ at the amounts of 38 and $47.09 \mathrm{tha}^{-1}$, respectively, subsequently decreasing until the last amount (Figures $2 \mathrm{E}$ and F). These results demonstrate that the balanced supply of nutrients, provided by the green manure, led to gains in shoot and root dry matter. 
A.

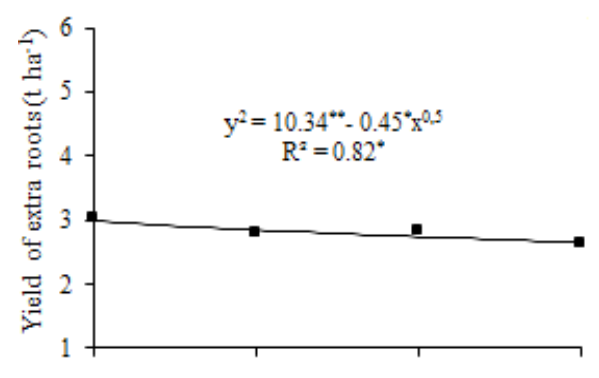

D.

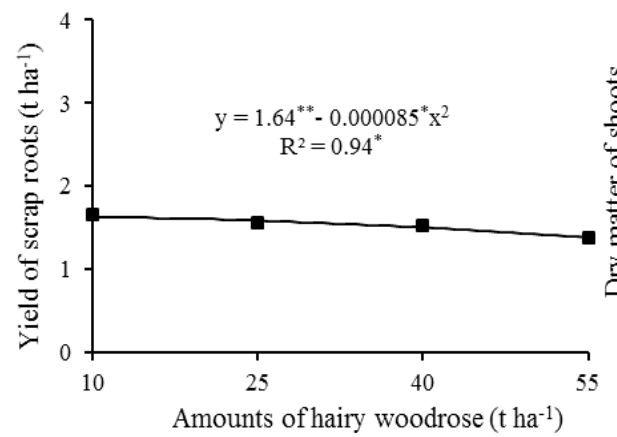

B.

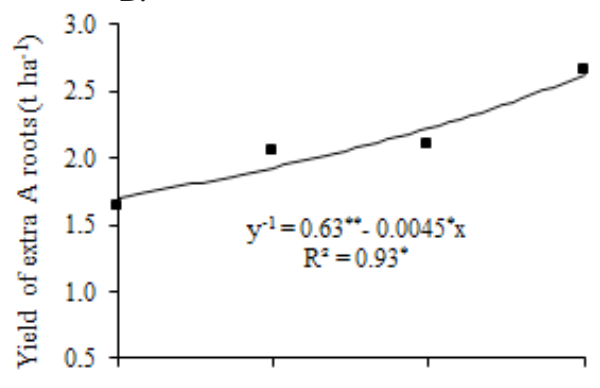

E.

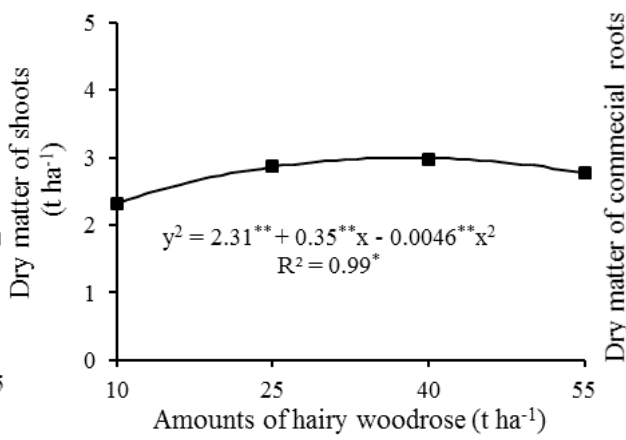

C.

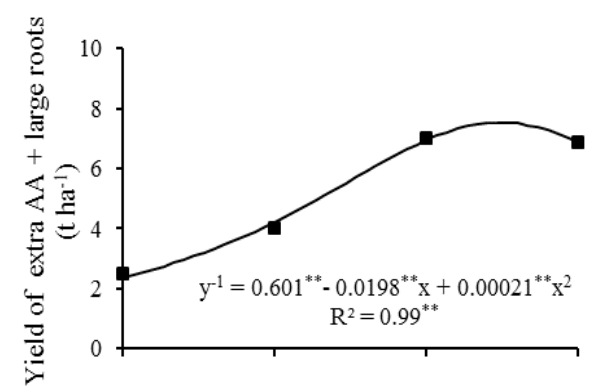

F.

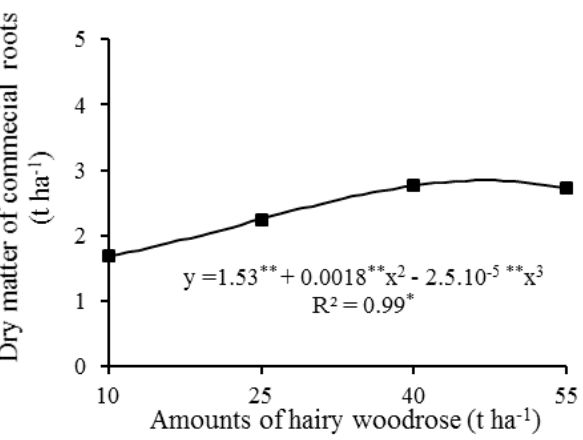

Figure 2. Yield of extra roots (A), extra A roots (B), extra AA + large roots (C), scrap roots (D), dry matter of shoots (E) and dry matter of commercial roots (F) of beet as a function of amounts of hairy woodrose incorporated to the soil

For green cowpea, increasing performance was observed for the number of pods $\mathrm{m}^{-2}$, yield of green pods, number of grains per pod, yield of green grains, dry matter of grains and dry matter of green pods as a function of the increase in the amounts of hairy woodrose incorporated to the soil, obtaining maximum values of $133.19,4.09,8.27,2.09,0.63$ and $0.19 t$ $\mathrm{ha}^{-1}$ at the hairy woodrose amount of $55 \mathrm{t} \mathrm{ha}^{-1}$, respectively (Figure 3A-F).

Such increasing performance in the evaluated characteristics of green cowpea is due to the increment in hairy woodrose amounts and to the benefits of the green manuring to the soil.
These effects include the increase in the contents of nutrients in the soil, especially nitrogen, highly required by vegetables, increase in organic matter percentage, decrease in acidity and toxic aluminum (Bezerra Neto et al., 2014), as well as improvement in soil fertility and water retention.

Another important factor that must be taken into consideration is that this positive effect on the crops, with the green manuring, does not come only from the contents of nutrients released by the hairy woodrose amounts incorporated to the soil, but also from the synchrony with which these nutrients are released and absorbed by plants (Silva et al., 2013).
A.

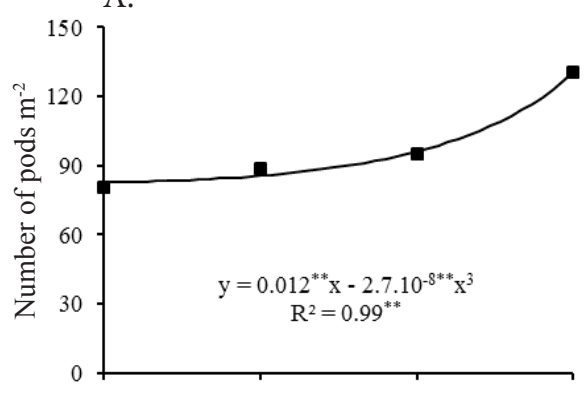

D.

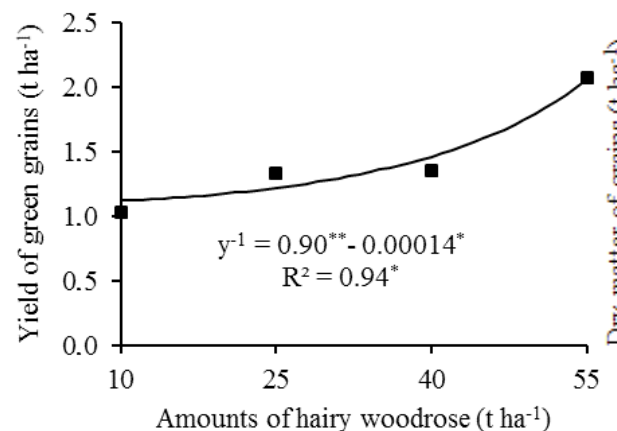

B.

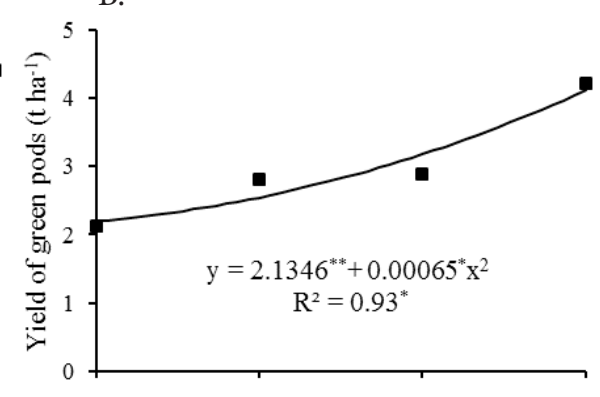

E.
C.

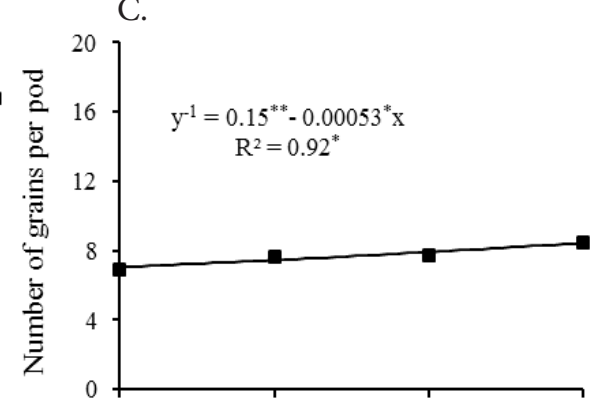

F.
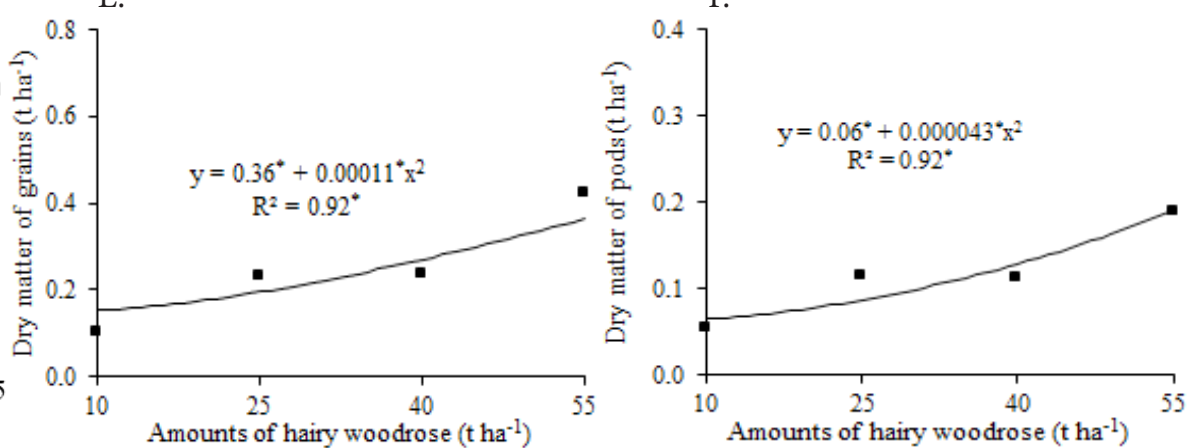

Figure 3. Number of pods $\mathrm{m}^{-2}(A)$, yield of green pods (B), number of grains per pod (C), yield of green grains (D), dry matter of grains (E) and dry matter of pods (F) of vegetable cowpea as a function of hairy woodrose amounts incorporated to the soil 
A.

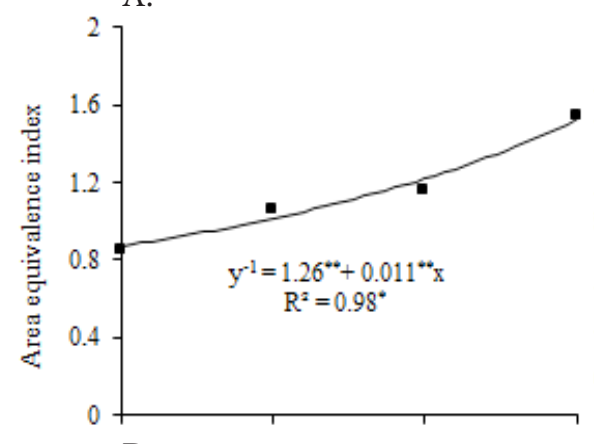

D.
B.

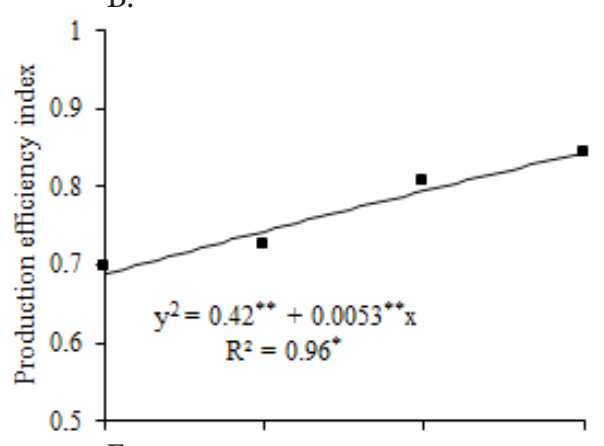

E.
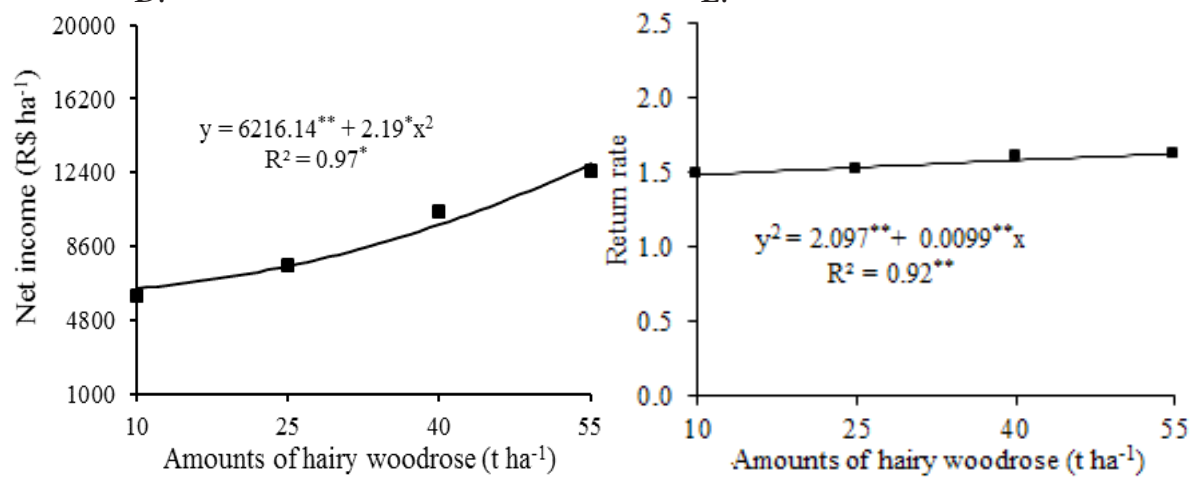

C.

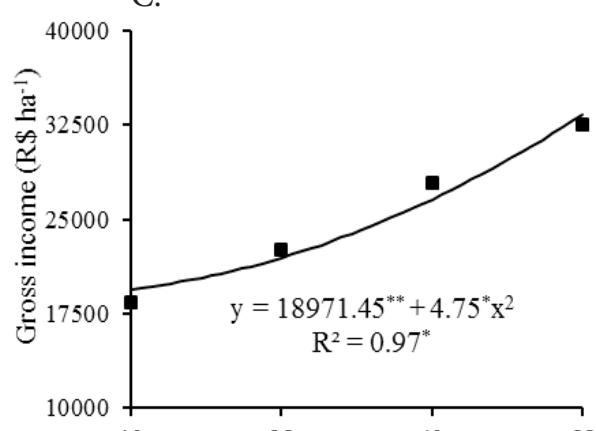

F.

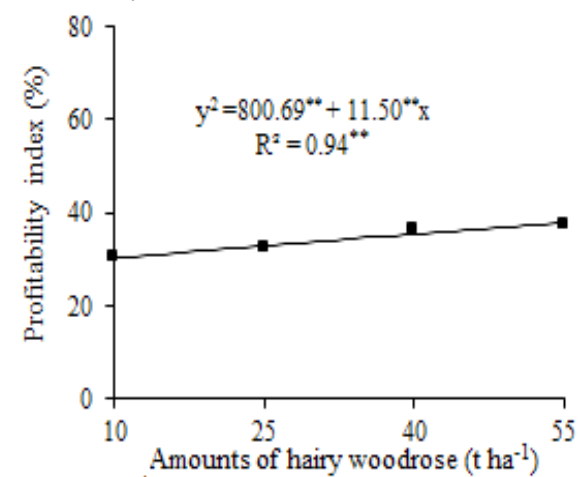

Figure 4. Area equivalence index (A), production efficiency index (B), gross income (C), net income (D), return rate (E) and profitability index $(F)$ of the intercropping of beet $x$ vegetable cowpea as a function of hairy woodrose amounts incorporated to the soil

The results found for the number of pods per $\mathrm{m}^{2}$, number of grains per pod, yield of green grains and dry matter of grains, equal to $133.19,8.27,2.09$ and $0.63 \mathrm{tha}^{-1}$ at the highest amount of hairy woodrose $\left(55 \mathrm{t} \mathrm{ha}^{-1}\right)$ incorporated to the soil, differed from those found by Pereira et al. (2016), who analyzed the productive performance of the intercropping of green cowpea and radish under different amounts of 'flor-de-seda' (Calotropis procera) biomass incorporated to the soil, and obtained values of $159.6,8.5,3.60$ and $1.30 \mathrm{tha}^{-1}$, respectively.

For the agro-economic indices evaluated: area equivalence index, production efficiency index, gross income, net income, return rate and profitability index, the highest values were 1.53 , $0.84, \mathrm{R} \$ 33,340.20, \mathrm{R} \$ 12,840.89,1.62$ and $37.86 \%$, obtained using the highest amount of hairy woodrose $\left(55 \mathrm{t} \mathrm{ha}^{-1}\right)$, respectively (Figures $4 \mathrm{~A}, \mathrm{~B}, \mathrm{C}, \mathrm{D}, \mathrm{E}$ and F).

The obtained value of AEI, 1.53, reflects the positive effect on food production per unit of area in this cultivation system because, when AEI higher than 1 is obtained in the intercropping, the growth and production of the involved crops are favored, indicating better use of natural resources. This information can be confirmed by Custódio et al. (2015), who comments that: when AEI is equal to 1.0, there is no difference between the cultivation systems; when higher than 1.0, the intercropping will be advantageous; and when lower than 1.0, the intercropping will compromise the production.

Thus, according to the result of AEI obtained here, the crops composing the intercropping complemented one another, efficiently using the environmental resources, allowing for better use of the land.

Regarding the economic indices, it can be highlighted that beet intercropped with vegetable cowpea responded very well to the green manuring, which was demonstrated by the promising values of the economic indicators and, therefore, the agronomic efficiency of the beet and vegetable cowpea crops was translated into economic efficiency. Such positive performance was promoted by the better use of the environmental resources by the crops composing the intercropping system, compared with the mono cultivation system (Favacho et al., 2017).

\section{Conclusions}

1. Hairy woodrose amount of $55 \mathrm{t} \mathrm{ha}^{-1}$ incorporated to the soil led to the best agro-economic efficiency of the intercropping of beet and green cowpea.

2. Using the hairy woodrose species as green manure is agro-economically viable in intercropping systems with beet and green cowpea.

\section{Literature Cited}

Almeida, A. E. S.; Bezerra Neto, F.; Costa, L. R.; Silva, M. L.; Lima, J. S. S. Barros Júnior, A. P. Eficiência agronômica do consórcio alface-rúcula fertilizado com flor-de-seda. Revista Caatinga, v.28, p.79-85, 2015. https://doi.org/10.1590/1983-21252015v28n309rc Alves, J. M. A.; Araújo, N. P.; Uchôa, S. C. P.; Albuquerque, J. A. A.; Silva, A. J. Rodrigues, G. S.; Silva, D. C. O. Avaliação agroeconômica da produção de cultivares de feijão-caupi em consórcio com cultivares de mandioca em Roraima. Revista Agro@mbiente On-line,v.3, p.15-30, 2009.

Bezerra Neto, F.; Oliveira, L. J.; Santos, A. P.; Lima, J. S. S.; Silva, I. N. Otimização agroeconômica da cenoura fertilizada com diferentes doses de jitirana. Revista Ciência Agronômica, v.45, p.305-311, 2014. https://doi.org/10.1590/S1806-66902014000200011 
Charnes, A.; Cooper, W. W.; Rhodes, E. Measuring the efficiency of decision-making units. European Journal of Operational Research, v.2, p.429-444, 1978. https://doi.org/10.1016/0377-2217(78)90138-8

Custódio, A. M.; Alves, E. M.; Paim, T. P.; Carneiro, H. A.; Lima Junior, A. F. Desempenho agronômico de consórcios entre rabanete e alface no oeste goiano. Revista Verde de Agroecologia e Desenvolvimento Sustentável, v.10, p.56-60, 2015. https://doi. org/10.18378/rvads.v10i5.3828

Devide, A. C. P.; Ribeiro, R. L. D.; Valle, T. L.; Almeida, D. L.; Castro, C. M.; Feltran, J. C. Produtividade de raízes de mandioca consorciada com milho e caupi em sistema orgânico. Bragantia, v.68, p.145153, 2009. https://doi.org/10.1590/S0006-87052009000100016

EMBRAPA - Empresa Brasileira de Pesquisa Agropecuária. Manual de análises químicas de solos, plantas e fertilizantes. 2.ed. Brasília: Embrapa Informação Tecnológica, 2009. 627p.

Favacho, F. S.; Lima, J. S. S.; Bezerra Neto, F.; Silva, J. N.; Barros Júnior, A. P. Eficiência produtiva e econômica do consórcio de cenoura $\mathrm{x}$ caupi proveniente de adubação verde e arranjos espaciais. Revista Ciência Agronômica, v.48, p.337-346, 2017.

Fernandes, Y. T. D; Lima, J. S. S.; Câmara, F. M.; Silva, M. I. L.; Lima, V. I. A. Desempenho agronômico do coentro consorciado com cenoura sob diferentes arranjos espaciais e quantidades de jitirana incorporadas ao solo. Horticultura Brasileira, v.29, p.1973-1980, 2011.

Ferreira, D. F. Sisvar: A computer statistical analysis system. Ciência e Agrotecnologia, v.35, p.1039-1042, 2011. https://doi.org/10.1590/ S1413-70542011000600001

Jandel Scientifc. Table curve: Curve fitting software. Corte Madera: Jandel Scientific, 1991. 280p.

Lima, J. S. S.; Bezerra Neto, F.; Negreiro, M. Z.; Ribeiro, M. C. C.; Barros Júnior, A. P. Productive performance of carrot and rocket cultivars in strip-intercropping system and sole crops. Agrociencia, v.44, p.561-574, 2010.

Linhares, P. C. F.; Sousa, A. J. P.; Pereira, M. F. S.; Alves, R. F.; Maracajá, P. B. Beterraba fertilizada sob diferentes doses de palha de carnaúba incorporada ao solo. Agropecuária Científica no Semi-Árido, v.8, p71-76, 2012.
Oliveira, M. K. T.; Bezerra Neto, F.; Barros Júnior, A. P.; Lima, J. S. S.; Moreira, J. N. Desempenho agronômico da cenoura adubada com jitirana antes de sua semeadura. Revista Ciência Agronômica, v.42, p.364-372, 2011. https://doi.org/10.1590/ S1806-66902011000200015

Pereira, M. F. S.; Bezerra Neto, F.; Pontes, F. S. T.; Linhares, P. C. F. Silva, M. L.; Silva, Í. N. Productive performance of cowpea-radish intercropping under different amounts of rooster tree biomass incorporated into the soil. Revista Brasileira de Engenharia Agrícola e Ambiental, v.20, p.965-971, 2016. https://doi. org/10.1590/1807-1929/agriambi.v20n11p965-971

Santos, C. A. F. Cultivares de feijão-caupi para o vale do São Francisco. Petrolina: Embrapa Semiárido, 2011. 10p. Circular Técnica, 94

Sediyama, M. A. N.; Santos, I. C.; Lima, P. C. Cultivo de hortaliças no sistema orgânico. Revista Ceres, v.61, p.829-837, 2014. https:// doi.org/10.1590/0034-737x201461000008

Silva, J. N.; Bezerra Neto, F.; Lima, J. S. S.; Rodrigues, G. S. O.; Barros Júnior, A. P.; Chaves, A. P. Combinations of coriander and salad rocket cultivars in bicropping systems intercropped with carrot cultivars. Revista Caatinga, v.30, p.125-135, 2017. https://doi. org/10.1590/1983-21252017v30n114rc

Silva, M. L.; Bezerra Neto, F.; Linhares, P. C. F.; Bezerra, A. K. H. Produção de cenoura fertilizada com flor-de-seda (Calotropis procera (Ait.) R.Br.). Revista Ciência Agronômica, v.44, p.732740, 2013. https://doi.org/10.1590/S1806-66902013000400009

Silva, M. L.; Bezerra Neto, F.; Linhares, P. C. F.; Sá, J. R.; Lima, J. S. S.; Barros Júnior, A. P. Produção de beterraba fertilizada com jitirana em diferentes doses e tempos de incorporação ao solo. Revista Brasileira de Engenharia Agrícola e Ambiental, v.15, p.801809, 2011. https://doi.org/10.1590/S1415-43662011000800006

Silva, M. G.; Sharma, R. D.; Junqueira, A. M. R.; Oliveira, C. M. Efeito da solarização, adubação química e orgânica no controle de nematóides em alface sob cultivo protegido. Horticultura Brasileira, v.24, p.489-494, 2006. https://doi.org/10.1590/S010205362006000400019 